\title{
Аналіз умов і факторів, що впливають на якість підбору і розстановки кадрів в органах військового управління
}

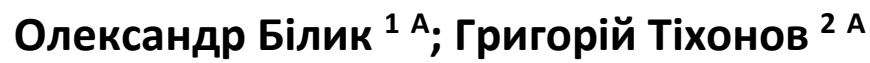 \\ А Національний університет оборони України імені Івана Черняховського, пр-кт Повітрофлотський, 28, м. Київ, 03049, України
}

Received: March 29, 2021 | Revised: April 21, 2021 | Accepted: April 30, 2021

DOI: $10.33445 /$ sds.2021.11.2.10

\begin{abstract}
Анотація
На сучасному етапі будівництва й розвитку Збройних Сил України однієї з найважливіших $\epsilon$ проблема створення ефективної системи управління військами. Рівень професійної придатності посадових осіб органів військового управління значно впливає на ефективність функціонування всієї системи, що обумовлює важливість і необхідність підвищення якості підбору і розстановки кадрів. Відповідно метою статті $\epsilon$ розглянути сукупність умов і факторів, які необхідно враховувати при підборі і розстановці кадрів в органах військового управління. Автором проаналізовано умови і фактори, що впливають на якість підбору і розстановки кадрів в органах військового управління.
\end{abstract}

Ключові слова: персонал, підбір та розстановка кадрів, професійна підготовка, кадровий резерв.

\section{Постановка проблеми}

Стратегія розвитку Збройних Сил України, забезпечення реалізації державної політики в галузі оборони в сучасних умовах зумовлюють необхідність реалізації заходів комплексного вирішення завдань їх кадрового забезпечення, концентрації та якісного використання фінансових та матеріально-технічних ресурсів, комплектування професійно підготовленими кадрами з потенціалом та перспективами подальшого службового зростання [1]. Сучасний стан кадрової політики та кадрової роботи вимагає більш глибокого розуміння системи управління кар'єрою офіцера 3 метою максимального підвищення кількості посад зайнятих компетентними та високопрофесійними командирами та начальниками. Якість офіцерського корпусу Збройних Сил та ефективність військового керівництва прямо залежить від успішного управління кар'єрою кожного офіцера протягом всього періоду служби. Отже, важливою задачею командирів (начальників) та органів кадрової роботи $\epsilon$ підбір i розстановка найбільш перспективних та підготовлених офіцерів 3 перших років служби з метою забезпечення ефективності їх кар'єрного просування в органах військового управління. Цей напрямок роботи включає в себе декілька моментів, які і визначають актуальність даної статті. Планування та контроль підбору і розстановки кадрів в органах військового управління заключається в тому, що з моменту прийняття офіцера на службу у Збройні Сили України та до його звільнення необхідно організовувати планомірне горизонтальне та вертикальне просування офіцера в системі посад та військових звань. Офіцер повинен знати не тільки свої перспективи на короткостроковий та довгостроковий період, але й те, яких показників він повинен досягти, щоб мати можливість просування по службі в органах військового управління.

\footnotetext{
${ }^{1}$ Corresponding author: Здобувач наукового ступеня, e-mail: alexanderbilyk@ukr.net, ORCID: 0000-0002-9472-2383

2 к.в.н., старший науковий співробітник, начальник кафедри, e-mail: tikhonov2404@ukr.net, ORCID: 0000-0003-1941-744X
} 


\section{Аналіз останніх досліджень та публікацій}

У загальному виді, рівень підготовленості посадових осіб органів військового управління враховувався при дослідженні ефективності системи управління в наукових працях А. І. Аниська, П. К. Алтухова, С. Ф. Викулова, Е. І. Гусєва, В. В. Проданца.

Разом з тим у роботах С. Ф. Викулова не розглядалися фактори властивостей особистості, який $€$ ваговим при оцінці ефективності функціонування системи управління військами вважалися величинами заданими (рівними одиниці). У той же час, у дослідженнях В.В.Проданца при визначенні рівня підготовленості посадової особи органів військового управління, облік властивостей особистості взагалі не розглядається.

Фактори властивостей особистості для оцінки ефективності функціонування органів військового управління були враховані в методиці П. К. Алтухова.

Крім того, аналіз досліджень і теоретичних напрацювань вітчизняної військової науки свідчить, що питанням комплектування людськими ресурсами збройних сил значну увагу приділяли Л. С. Демидко, Є. Ф. Шелест, В.Г. Лішавський, Ю.А. Гусак, В. М. Артюх, І. С. Романченко, Ю. Є. Рєпіло, М. П. Думенко, В. В. Хома, В. М. Пасічник, О.О. Сурков, які свого часу зробили вагомий внесок у наукове дослідження цих питань, але вирішуючи наукові завдання, зумовлені актуальними проблемами практики свого часу, переважно в умовах мирного часу, розглядали показники і фактори, які найповніше відображали актуальні для них процеси.

\section{Постановка завдання}

Теоретичні положення, що існують, i практичні підходи до процесу підбору і розстановки кадрів в органах військового управління не повністю забезпечують виконання завдань, які стоять перед системою управління кар'єрою офіцера.

Враховуючи це, виникає необхідність у дослідженні системи підбору і розстановки Виклад основного матеріалу

Для аналізу умов і факторів, що впливають на якість підбору і розстановки кадрів в органах військового управління доцільно уточнити поняття - “підвищення якості підбору і розстановки кадрів".

Відповідно до існуючих визначень, якість це та або інша властивість, ознака, що визначає відповідність чого-небудь певним вимогам. Стосовно до предмету дослідження, і 3 врахуванням того, що система підбору кадрів повинна забезпечити відповідність посадових осіб певним вимогам, доцільно використовувати визначення; "Якість - це сукупність характеристик об'єкту, що відносяться до його здатності задовольняти встановлені i передбачувані потреби" [2]. кадрів в органах військового управління за рахунок дослідження умов і факторів, які необхідно враховувати при підборі i розстановці кадрів в органах військового управління.

Метою статті $\epsilon$ аналіз умов і факторів, що впливають на якість підбору і розстановки кадрів в органах військового управління.

Підбір кадрів розглядається, як комплекс заходів оцінки й прийняття на конкретні посади, які містять у собі ідентифікацію, тобто зіставлення вимог посади і кваліфікації посадової особи, його професійного досвіду, а також ділових і персональних якостей [3]. Виходячи із цього, підбір кадрів полягає у визначенні психологічних і професійних якостей посадових осіб із метою визначення їх відповідності конкретної діяльності. На підставі підбору відбувається розстановка кадрів по посадах.

Отже, під підвищенням якості системи підбору і розстановки кадрів в органах військового управління слід розуміти процес визначення сукупності необхідних професійних і психологічних якостей 
посадових осіб, найбільшою мірою задовольняючих заданим вимогам по реалізації управлінської діяльності, і їх розміщення по конкретних посадах в органах військового управління.

Основним змістом діяльності посадових осіб органів військового управління $\epsilon$ вироблення і реалізація адекватного обстановці управлінського рішення, від якого залежить рівень бойової і мобілізаційної готовності підлеглих структурних підрозділів та ефективність виконання ними завдань.

Як підсумок, сутність системи підбору і розстановки кадрів буде полягати в здійсненні процесу визначення необхідних якостей посадових осіб, які дозволять йому успішно здійснювати діяльність по

\begin{abstract}
виробленню й реалізації управлінського рішення, і співставлення із заданими вимогами.
\end{abstract}

Система підбору і розстановки кадрів залежить від багатьох факторів. Виходячи 3 існуючих визначень фактору, як причини, рушійної сила якого-небудь процесу, явища, що визначає його характер або окремі риси [4], а також, як моменту, істотної обставини в якому-небудь процесі, явищі [2], їх можна поділити на три умовні блоки: нормативноправові, соціально-демографічні та ті, що відображають зміст професійної діяльності (професійно-ділові). Сукупність факторів, що впливають на підбір і розстановку кадрів в органах військового управління, наведена на мал. 1.

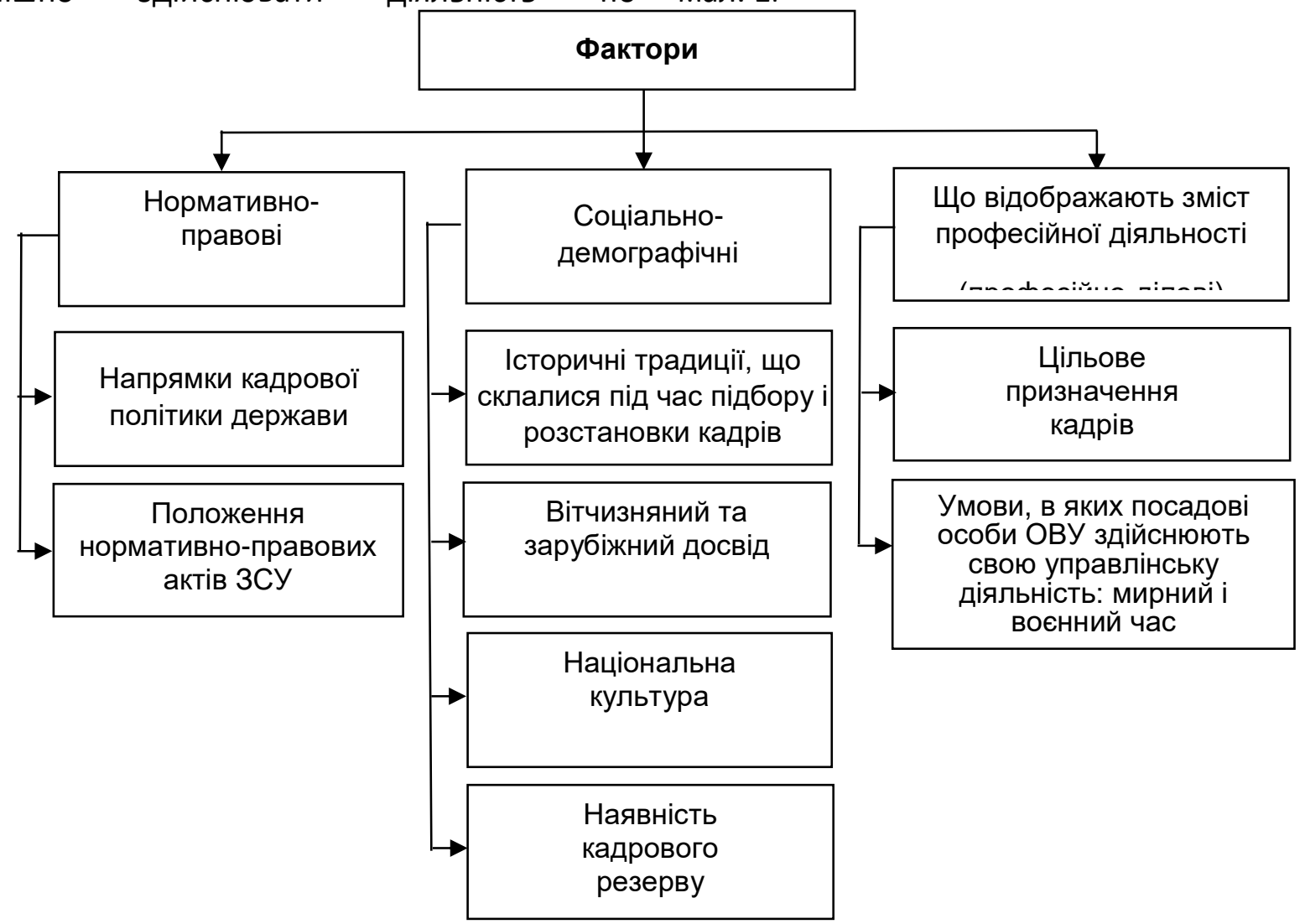

Мал. 1 Сукупність факторів, що впливають на підбір і розстановку кадрів в органах військового управління

Фактори нормативно-правового блоку враховують вплив існуючої нормативної правової бази на процес розміщення кадрів. При цьому необхідно відзначити, що система підбору i розстановки кадрів в органах військового управління відповідає основним напрямкам кадрової політики Збройних Сил України. Основною вимогою $є$ забезпечення відповідності ії рівня професійної підготовленості посадової особи до якісного виконання обов'язків за посадою, на яку ії призначено. 
у факторах соціально-демографічного блоку необхідно виділити історичні традиції, що склалися та досвід підбору і розстановки кадрів, а також наявність кадрового резерву в органах військового управління.

Традиції системи підбору і розстановки кадрів базуються на обліку як вітчизняного, так і закордонного досвіду, особливостей кадрової політики, що залежить, у тому числі, від національної культури (наприклад, центральної, західної й східної). Вони впливають одна на одну і розміщення кадрів, насамперед у сфері соціальних відносин і ґрунтуються переважно на персональних оцінках. Виходячи із цього, можна припустити, що дані фактори є несуттєвими, тому що не мають юридичної сили, отже, не можуть ураховуватися.

Поряд з перерахованими, слід розглянути такий фактор, як наявність кадрового резерву. Необхідно відзначити, що система передбачає здійснення підбору кадрів як у самому органі військового управління, так i поза його межами, висування або ротації посадових осіб. При цьому повинен ураховуватися тільки той кадровий резерв, який відповідає заданим вимогам до рівня підготовленості посадової особи, де, насамперед, ураховується рівень її професійної підготовки.

Таким чином, зазначені фактори, обумовлюють вимоги переважно до професійної придатності посадової особи органів військового управління, заснованих на обліку їх щорічного оцінювання, які можна віднести до так званих факторів внутрішнього середовища (підготовленості самої посадової особи).

Фактори змісту професійної діяльності містять У собі такі фактори, як цільове призначення посадової особи і фактор середовища, у якому здійснюється управлінська діяльність.

Цільове призначення кадрів вимагає обліку виду і змісту виконуваних ними управлінських завдань. У результаті, повинно бути визначено, що необхідно знати посадовій особі, уміти, про що мати уявлення. Тобто, визначається його інтелектуальна складова властивостей особистості.

Фактор середовища, в якому здійснюється управлінська діяльність, також висуває вимоги до властивостей особистості посадової особи. Дані вимоги, у загальному виді, характеризуються умовами, у яких посадові особи органів військового управління здійснюють свою управлінську діяльність: мирного і воєнного часу.

У мирний час діяльність посадової особи по виробленню і реалізації управлінського рішення здійснюється в умовах: передбачуваного розвитку обстановки; достатньої кількості часу на збір інформації і ухвалення рішення; плановості реалізації заходів; відсутності (незначному ступеня) негативного інформаційного впливу.

Це вимагає від посадової особи відповідного рівня розвитку властивостей особистості, що забезпечує вироблення й ухвалення управлінського рішення в умовах інформаційної визначеності і відсутності ризику.

У воєнний час діяльність посадових осіб по виробленню управлінського рішення здійснюється в умовах, які формуються змістом сучасної операції (бойових дій): значне зростання обсягу швидкоплинної інформації, що змінюється або впливає на прийняття рішення; динаміка бойових дій; масове застосування високотехнологічної й високоточної зброї; необхідність безперервної взаємодії із силами й засобами інших військ і військових формувань, різних структур воєнної організації держави, у тому числі силами й засобами територіальної оборони, органами місцевої влади; безперервний інформаційний вплив противника; активні дії сил спеціальних i психологічних операцій противника i екстремістсько-налаштованих злочинних збройних груп [5; 6].

Це обумовлює для посадових осіб органів військового управління необхідність: ухвалювати й обробляти, в порівнянні 3 мирним часом, значно більший потік інформації; виробляти й ухвалювати управлінські рішення в умовах інформаційної невизначеності, обмеженого часу, постійного 
інформаційно-психологічного впливу, тиску і ризику; здійснювати стійке управління (взаємодію) більшою, ніж у мирний час кількістю об'єктів управління в постійно напружених умовах обстановки.

\section{Висновки}

Таким чином, у ході проведення дослідження установлено, що основним змістом діяльності посадової особи органів військового управління $\epsilon$ вироблення управлінського рішення. Якість управлінського рішення залежить від рівня знань, навичок, умінь і персональних якостей посадової особи.

Аналіз вироблення управлінського рішення дозволяє визначити фактори внутрішнього і зовнішнього середовища, що впливають на підбір і розстановку посадових осіб, які приймали участь у даному процесі.

Внутрішнє середовище представлене факторами, що обумовлюють вимоги до професійної придатності посадової особи. Зовнішнє середовище - факторами, що обумовлюють психологічну складову особистості. При цьому виявлено, що
Отже, підвищення якості системи підбору і розстановки кадрів в органах військового управління полягає у підборі посадових осіб які мають необхідні якості або спроможні ними оволодіти.

властивості особистості в різному ступені впливають на управлінську діяльність посадової особи у критично складних ситуаціях, що визначене різним ступенем стійкості окремих психологічних процесів у тих самих індивідів і вимагає їхнього роздільного обліку в мирний і воєнний час.

Виявлені фактори, що впливають на процес вироблення i реалізацію управлінського рішення, дозволяють сформувати вимоги, які необхідно враховувати при підборі і розстановці посадових осіб в органах військового управління: відповідний рівень знань, навичок і вмінь, розвитку персональних властивостей посадової особи; здатність до реалізації управлінських завдань у мирний і воєнний час.

\section{Список використаних джерел}

1. Концепція військової кадрової політики у Збройних Силах України на період до 2020 року: наказ Міністерства оборони України № 342 від 26.06.2017 p. URL: http://www.mil.gov.ua/diyalnist/kadrovapolitika/konczepcziya-kadrovoi-politiki-vzbrojnih-silah-ukraini/ (дата звернення 30.03.2021).

2. Сучасний тлумачний словник української мови: 100000 слів / за заг. ред. д-ра філол. наук, проф. В.В. Дубічинський. Харків : ВД “ШКОЛА", 2008. 1008 с.

3. Підбір кадрів. [Електронний ресурс]. 2010. Режим доступу: URL: http://www.кadrovik.ua/modules.php (дата звернення 30.03.2021).

4. Хміль Ф. І. Основи менеджменту: підручник. Київ: Академвидав, 2003. 608 с.

5. Дымов Н.Г. Основные направления совершенствования деятельности органов управления оперативного звена. Военная мысль. 2005. № 6. С. 31-37.

6. Юсупов Р. М. Пути комплексного исследования устойчивости управления войсками (силами) Военная мысль. 1991. № 11. С. 16-21.

7. Думенко М. П. Роль і місце кадрової політики у Збройних Силах України в процесі їх реформування та розвитку. URL: http://archive.nndiuvi.org.ua/

fulltext.html?id=1917. (дата звернення 30.03.2021).

8. Артюх В. М. Забезпечення комплектування Збройних Сил України особовим складом: стан, проблеми та напрями удосконалення. Наука і оборона. 2010. № 1. С. 13-21.

9. Клепіков В. Ф. Досвід комплектування збройних сил розвинутих країн світу особовим складом та можливість його застосування в Збройних Силах України. Збірник наукових праць ЦНДІ ЗС України. 
Київ ЦНДІ ЗСУ. 2014. № 2(68). С. 336-345.

10. Казан П. И., Шпанчук Г. В. Методический подход к оценке индивидуальных возможностей

различных категорий. Специализи- рованный научный журнал "Научные труды Академии Пограничной службы КНБ Республики Казахстан". 2014. № 1. С. 51-56.

\title{
Анализ условий и факторов, которые влияют на качество подбора и расстановки кадров в органах военного управления
}

\author{
Александр Билык ${ }^{1}$; ;ригорий Тихонов ${ }^{2 \text { A }}$ \\ ${ }^{1}$ Corresponding author: Соискатель ученой степени, e-mail: alexanderbilyk@ukr.net, ORCID: 0000-0002-9472-2383 \\ ${ }^{2}$ канд. воен. наук, старший научный сотрудник, нач. кафедры, e-mail: tikhonov2404@ukr.net, ORCID: 0000-0003-1941-744X \\ А Национальный университет обороны Украины имени Ивана Черняховского, пр-кт Воздухофлотский, 28, г. Киев, 03049, Украина
}

\begin{abstract}
Аннотация
На современном этапе строительства и развития Вооруженных Сил Украины одной из важнейших является проблема создания эффективной системы управления войсками. Уровень профессиональной пригодности должностных лиц органов военного управления значительно влияет на эффективность функционирования всей системы, обусловливает важность и необходимость повышения качества подбора и расстановки кадров. Целью статьи является рассмотрение совокупности условий и факторов, которые необходимо учитывать при подборе и расстановке кадров в органах военного управления. Автором проанализированы условия и факторы, влияющие на качество подбора и расстановки кадров в органах военного управления.
\end{abstract}

Ключевые слова: персонал, подбор и расстановка кадров, профессиональная подготовка, кадровый резерв.

\section{Analysis of conditions and factors that affect the quality of the selection and placement of personnel in military command and control bodies}

\author{
Aleksandr Bilyk ${ }^{1}$ A; Grigory Tikhonov ${ }^{2}$ A \\ ${ }^{1}$ Corresponding author: Applicant for a scientific degree, e-mail: alexanderbilyk@ukr.net, ORCID: 0000-0002-9472-2383 \\ ${ }^{2}$ Candidate of Military Sciences, Senior Researcher, Head of the Department, e-mail: tikhonov2404@ukr.net, ORCID: 0000-0003-1941-744X \\ A National Defence University of Ukraine named after Ivan Cherniakhovskyi, 28, Povitroflotskyi Ave, Kyiv, 03049, Ukraine
}

\begin{abstract}
At the present stage of construction and development of the Armed Forces of Ukraine, one of the most important is the problem of creating an effective command and control system. The level of professional suitability of officials of military command and control bodies significantly affects the efficiency of the functioning of the entire system, makes it important and necessary to improve the quality of selection and placement of personnel. The purpose of the article is to consider a set of conditions and factors that must be taken into account in the selection and placement of personnel in military command and control bodies. The author analyzes the conditions and factors affecting the quality of the selection and placement of personnel in the military command and control bodies.
\end{abstract}

Keywords: personnel, selection and placement of personnel, professional training, personnel reserve. 


\section{References}

1. The concept of military personnel policy in the Armed Forces of Ukraine for the period up to 2020: order of the Ministry of Defense of Ukraine № 342 dated 26.06.2017 Available from: http://www.mil.gov.ua/diyalnist/kadrovapolitika/konczepcziya-kadrovoi-politiki-vzbrojnih-silah-ukraini/ (data of application 30.03.2021).

2. Modern explanatory dictionary of the Ukrainian language: 100,000 words / per general. ed. Dr. Philol. Sciences, Prof. V.V. Dubichynsky. Kharkiv: VD "SCHOOL", 2008. $1008 \mathrm{p} /$

3. Recruitment. [Electronic resource]. 2010. Access mode: Available from: http://www. kadrovik.ua/modules.php (data of application 30.03.2021).

4. Khmil F. I. Fundamentals of management: a textbook. Kyiv: Akademvydav, 2003. 608 p.

5. Dymov N. G. The main directions of improving the activities of the operational management. Military thought. 2005. № 6. P. 31-37.

6. Yusupov R. M. Ways of complex research of stability of management of armies (forces) Military thought. 1991. № 11. P. 16-21.
7. Dumenko M. P. The role and place of personnel policy in the Armed Forces of Ukraine in the process of their reform and development. Available from: http://archive.nndiuvi.org.ua/fulltext.html?i $d=1917$. (data of application 30.03.2021).

8. Artyukh V. M. Ensuring staffing of the Armed Forces of Ukraine with personnel: state, problems and areas of improvement. Science and defense. 2010. № 1. P. 13-21.

9. Klepikov V. F. Experience of staffing the armed forces of developed countries and the possibility of its application in the Armed Forces of Ukraine. Collection of scientific works of the Central Research Institute of the Armed Forces of Ukraine. Kyiv Central Research Institute of the Armed Forces of Ukraine. 2014. № 2(68). P. 336-345.

10. Kazan P. I., Shpanchuk G. V. A methodological approach to assessing the individual capabilities of servicemen of various categories. Specialized scientific journal "Scientific works of the Academy of the Border Guard Service of the National Security Committee of the Republic of Kazakhstan". 2014. № 1. P. 51-56. 